\title{
The impact of service quality drivers on customer satisfaction in internet provision services of Zimbabwe
}

\author{
Morelight Virima \\ Maxwell Sandada \\ Graduate School of Management, University of Zimbabwe \\ Tinashe TR Ndoro \\ Tinashe Chuchu \\ Department of Marketing Management \\ University of Pretoria, South Africa
}

Keywords

Service quality, customer satisfaction, internet provision, Zimbabwe

\begin{abstract}
The purpose of the research was to examine the impact of service quality on customer satisfaction amongst customers in the internet service provision sector of Zimbabwe. In the study, service quality consisted of six dimensions, namely, reliability, empathy, responsiveness, tangibles, location and price. The study employed a cross-sectional quantitative design from which a sample of 341 successfully completed questionnaires were obtained. Data analysis was performed using SPSS 23 software. Multiple regression was performed to ascertain the cause-effect relationship between the independent variables (namely, reliability, empathy, responsiveness, tangibles, location and price) and the dependent variable (customer satisfaction). The results of the study indicated that reliability, responsiveness and price displayed a positive statistically significant impact on customer satisfaction. On the other hand, empathy, tangibles and location were noted as not having a statistically significant positive impact on customer satisfaction. The main implication for internet service providers in Zimbabwe is that responsiveness and prices-sensitive offerings are key to satisfying customers.
\end{abstract}

Corresponding author: Tinashe Chuchu

Email addresses for the corresponding author: tinashe.chuchu@up.ac.za

First submission received: $20^{\text {th }}$ May 2019

Revised submission received: $9^{\text {th }}$ August 2019

Accepted: 21 ${ }^{\text {st }}$ August 2019

\section{Introduction}

Customer satisfaction has become an imperative subject, generating great interest within organisations, practitioners and researchers alike. The primary objective of organisations is to maximize profits whilst at the same time minimising costs. Profit maximisation can be achieved by increasing sales while reducing costs. Customer satisfaction is one of the most significant factors that can aid organizations to increase profits, customer satisfaction leads to customer loyalty which in turn leads to repeat purchases and referrals (Wilson, Zeithaml, Bitner \& Gremler, 2008). The universal challenge for businesses today is to move from product orientation to customer orientation. This challenge is becoming more difficult because customers are becoming increasingly sophisticated, educated and well informed. Customers have knowledge and high expectations of the service they want to receive from organisations. They now want greater choices and involvement in the purchasing process. The focus on customers/consumers has increased more as the consumption era also shifts to post-consumption. In the post-consumption era organizations are obliged to render more services in addition to what they currently provide to their customers. In this vein, it is imperative to gain insight of the levels of customer satisfaction and service 
quality experienced by customers. The Internet Service Provision (ISP) industry has become an increasingly competitive industry worldwide, in African and in Zimbabwe alike. Internet service providers that understand their customers' expectations and experiences are better positioned to implement focused performance initiatives designed to increase overall customer satisfaction, brand loyalty, and advocacy, and to maximize product penetration (Samen, Akroush \& Abu-Lail, 2013). The internet service provision sector in Zimbabwe is characterized by intense competition. Furthermore, the customer satisfaction index is low among Zimbabwean customers within this sector. To this end the issue of service quality and service delivery has become very important. From service quality stems the issue of customer satisfaction (Samen et al., 2013). Nonetheless, seeking to achieve a high level of customer satisfaction is one of the most challenging tasks for internet service providers in Zimbabwe as indicated by the lower customer satisfaction index.

The internet service provision sector is increasingly becoming more competitive and dynamic, thus internet service providers who guarantee customer satisfaction are more likely to survive in the market. Customer satisfaction is influenced by various service quality drivers which include, tangibility, reliability, responsiveness, assurance, empathy, price and location (Parasuraman, 1988). When customers are satisfied with the performance of a service, they often become loyal to it (Chen \& Chen, 2010; Mashwama, Chiliya \& Chuchu, 2019). Therefore, prioritising customer satisfaction makes businesses to become competitive and ultimately successful. According to Johnson and Gustafsson (2000) the process of satisfying and retaining current customers is far less expensive than constantly replacing customers. Hence, in the contemporary business environment keeping customers satisfied saves money as well as increasing profits for organisations. Furthermore, customer satisfaction creates repeat purchases and referrals (Johnson \& Gustafsson, 2000). In Zimbawe, the internet service provision sector is drastically growing, therefore making the concepts of customer satisfaction and service quality as key priorities. This means that for organisations who are internet service providers, it is imperative for them offer a superior service quality to their customers to ensure customer satisfaction and retention. Hence, this creates a gap in terms of studying and comprehending how service quality drivers influence customer satisfaction within the internet service provision sector in Zimbabwe.

The purpose of the study is to investigate the impact of the drivers of service quality (namely, tangibility, reliability, responsiveness, assurance, empathy, price and location) on customer satisfaction achieved by internet service providers in Zimbabwe. The drivers of service quality are noted as significant predictors of customer satisfaction (Parasuraman, 1988). Internet service providing organisations face a number of challenges as they operate in the turbulent business environment in Zimbabwe which impact on the satisfaction experienced by customers (Masevo, 2015). It can be noted that optimising on the level of service quality ensures a high level of customer satisfaction Gera (2011) which translates to increased sales and profits (Kotler, 2015). The objective of the present study is to investigate the impact of service quality drivers on customer satisfaction within the internet service provision sector, specifically looking at the largest internet service provider in Zimbabwe. In order to achieve the objective of the study, the following research question was proposed:

What is the impact of service quality drivers on customer satisfaction achieved by internet service providers in Zimbabwe?

\section{Literature Review}

In the present study, literature on customer satisfaction and service quality will be discussed. The literature review section will commence by providing a discussion of customer satisfaction followed by service quality and the SERVQUAL model.

\section{Customer satisfaction}

There is no single and standard generally accepted definition of customer satisfaction in literature since different scholars conceptualise the concept differently. Tahir, Waggett and Hoffman (2013) 
proposed that customer satisfaction is a customer's viewpoint based on the customer's expectation and then the customer's subsequent post purchase experience. This proposition is supported by Nguyen (2014), who argued that the customers' level of satisfaction is a result of cumulative consumer experiences. Maziriri and Madinga (2015) are of the view that if customer satisfaction is not met, the customer will experience buyer's remorse, and this justifies the need of customer satisfaction for retailers. Customer satisfaction is identifiable by a response from the customer (Giese \& Cote, 2000). In addition, customer satisfaction is generally a product of technology (Cheung \& Vogel, 2013; Koenaite, Chuchu \& Venter de Villiers, 2019). On the other hand, Kotler and Keller (2009) consider satisfaction to be an individual's feelings of pleasure or displeasure that result from comparing a product's perceived performance or quality or outcome with their expectations. The response can either be cognitive or affective. This response pertains to the purchase experience by the customer which occurs either during or after the purchase experience.

\section{Service quality}

There are various definitions that relate to the concept "service". Most of these definitions are dependent on the context in which the concept is being examined. Kotler and Keller (2009) define services as any intangible act or performance that one party offers to another. Services according to Kotler and Keller do not result in ownership. Eshghi (2008) suggested that services may also be described as an intangible offer by one person or organisation to another in return for money or pleasure. Solomon (2009) postulates that quality happens to be one of the most important things that customers look for in an offering of which service happens to be one. Kotler and Keller (2009) argued that quality is the entirety of features as well as characteristics of a product or services that bears on its capability to satisfy stated or implied needs. In this vein, Eshghi (2008) defined service quality as the overall assessment of a service by a customer. In the context of marketing management literature, Bowen and David (2005) suggest that service quality is the extent to which the customer's perceptions of service either meet or exceed their expectations. In light of this suggestion service quality can therefore be perceived as how good or how bad customers are served by a service provider. Ghylin, Green, Drury, Chen, Schultz, Uggirala, Abraham \& Lawson (2006) proposed that when organisations define service quality, they will be able to deliver services with a higher quality level thus resulting in an increase in customer satisfaction. On the other hand, Parasuraman (1988) defined service quality as the differences between customer's expectations and perceptions of service.

\section{Servqual model}

Parasuraman (1988) developed the SERVQUAL model which was operationalised as a 22-item instrument to measure service quality. The model emerged through studying the behaviour of customers in various service sectors, thereby resulting in 10 dimensions of quality, namely responsiveness, reliability, tangible, competence, courtesy, credibility, security access, communication and understanding. These dimensions were used to evaluate service quality of different organizations. The SERVQUAL model was constructed grounded on two elements: expectation and perception. Expectation captures the anticipated and required level in the service from the point of view of the customer. Perception on the other hand indicates a customer's judgment of a service based on their experience of that service. From a mathematical perspective, the model is expressed as follows, $\mathrm{SQ}=\mathrm{P}$-E: where $\mathrm{P}$, represents the service provider's behavioural performance, whilst E, represents the customers' expectations, with SQ, denoting service quality which is the gap between perceived and expected performance. Thus, the greater the positive score in the difference, the higher the service quality (Parasuraman, 1988).

\section{Proposed conceptual model}

To investigate the impact of service quality on customer satisfaction within the internet service provision sector in Zimbabwe, a unique model was developed based on the following proposed hypotheses. 


\section{Research hypotheses development}

Hypothesis 1: Sullivan, Suddeth, Vardell and Vojdani (1996)

Reliability has a statistically significant positive impact on customer satisfaction.

Hypothesis 2: Agnihotri, Dingus, Hu and Krush (2016)

Responsiveness has a statistically significant positive impact on customer satisfaction.

Hypothesis 3: Munusamy, Chelliah and Mun (2010)

Tangibles have a statistically significant positive impact on customer satisfaction.

Hypothesis 4: Lin (2007)

Empathy has a statistically significant positive impact on customer satisfaction.

Hypothesis 5: Anselmsson (2006)

Location has a statistically significant positive impact on customer satisfaction.

Hypothesis 6: Han and Ryu (2009)

Price has a statistically significant positive impact on customer satisfaction.

\section{Conceptual Model}

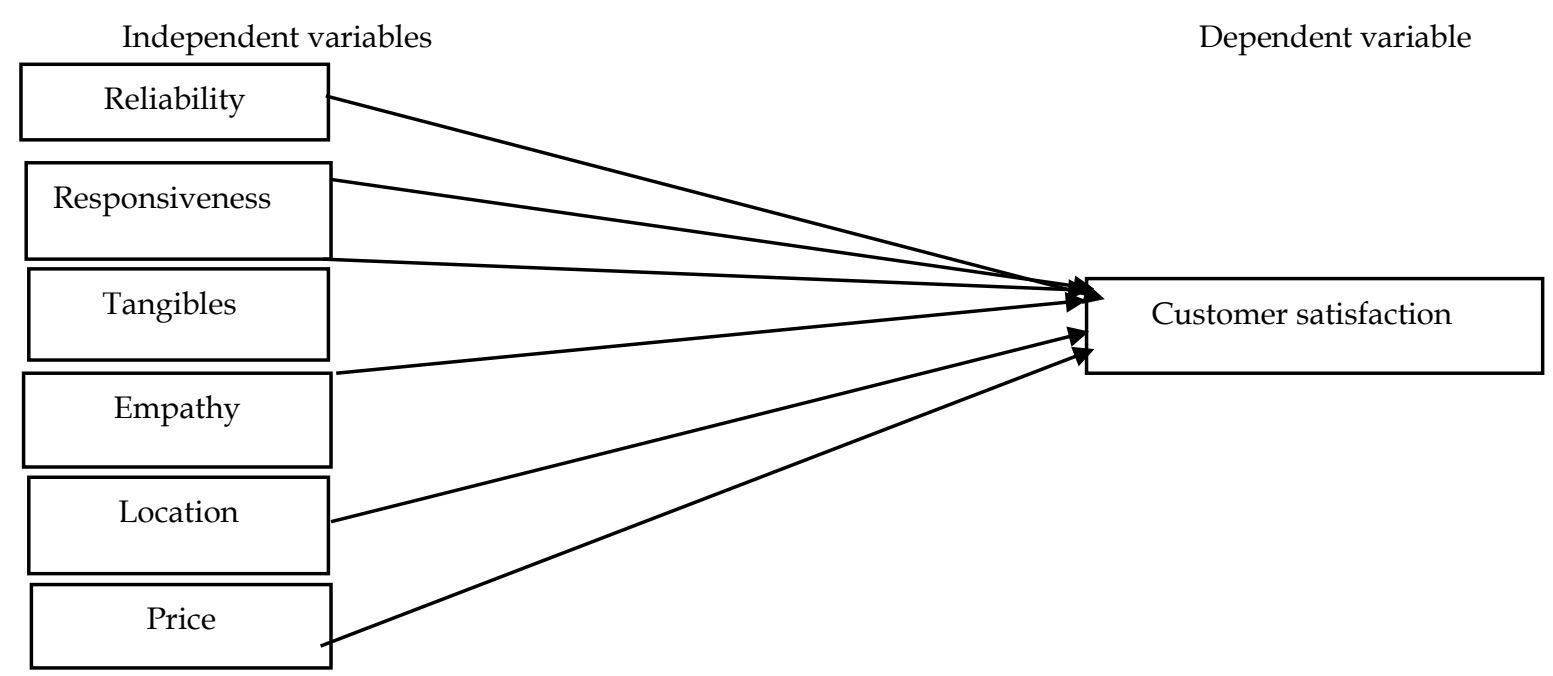

Figure 1: The conceptual framework for measuring the impact of service quality on customer satisfaction

\section{Research methodology}

Research Approach

A cross-sectional quantitative research design was followed in the study. The data was collected from a questionnaire adapted from previous empirical studies (Al-Wugayan \& Pleshko, 2010; Chidambaram, 2012; Parasuraman, 1988). The research participants included individuals who used the services of the biggest internet provider in Zimbabwe. The population comprised of 27,645 individuals. To determine the sample size, the formula developed Fox, Hunn and Mathers (2009) was used. The formula has a $\pm 5 \%$ margin of error. Through stratified random sampling a total of 341 usable completed questionnaires were obtained.

\section{Descriptive Statistical Analysis}

The researchers used descriptive statistics in form of frequency distributions and percentages to describe the demographics of the respondents such as gender, age, education and nature of users.

\section{Normality Test}

Before analysing the data, the researcher performed the test for normality. The significance of the normality test for the researcher was to ascertain the type of tests to carry out for correlation analysis, 
being either parametric or non-parametric tests. Normally distributed data uses parametric tests whereas unevenly distributed data uses non-parametric tests (Saunders, Lewis \& Thornhill, 2012). In carrying out normality tests, the Kolmogorov-Smirnov test is useful for significantly large sample sizes greater than 2000 whilst the Shapiro Wilk is useful for smaller sample sizes less than 2000. The sample size for this research was 341 respondents, therefore the Shapiro Wilk tests was best. From the Shapiro - Wilk test if the " $\mathrm{p}$ " value is greater than $0.05(\mathrm{p}>0.05)$ it indicates that data is normally distributed implying that the selected sample does not significantly vary from the study population hence, the parametric tests can then be performed using the data. If the " $\mathrm{p}$ " value is less than 0.05 , this implies that the data is unevenly distributed hence, non-parametric tests need to be performed. In the study, the " $p$ " value from the Shapiro - Wilk test was less than 0.05 , implying that the data was not normally distributed. In the vein, non-parametric tests were used in the data analysis.

\section{Regression Analysis}

In the study, in order to establish the cause and effect relationship between independent and dependent variables multiple regression analysis was performed.

\section{Validity and Reliability}

To measure the reliability of the research instrument (questionnaire) adopted in the study, the Cronbach's Alpha score was calculated. A Cronbach's Alpha score of at least 0.7 implies that the research instrument is reliable. The overall Cronbach's Alpha score obtained in the study was 0.914, which exceeded the minimum threshold score of 0.7 . Hence, the research instrument adopted in the study was reliable.

\section{Results}

Table 1: Descriptive Statistics

\begin{tabular}{|c|c|}
\hline \multicolumn{2}{|l|}{ Sample: 341} \\
\hline Gender & \\
\hline Males & $54 \%$ \\
\hline Female & $46 \%$ \\
\hline Total & $100 \%$ \\
\hline \multicolumn{2}{|l|}{ Age } \\
\hline $15-25$ & $4 \%$ \\
\hline $25-35$ & $49 \%$ \\
\hline $35-45$ & $43 \%$ \\
\hline $55-65$ & $3 \%$ \\
\hline $65+$ & $1 \%$ \\
\hline Total & $100 \%$ \\
\hline \multicolumn{2}{|l|}{ Educational level } \\
\hline Secondary education & $3 \%$ \\
\hline Bachelor's degree & $66 \%$ \\
\hline Other qualifications & $31 \%$ \\
\hline Total & $100 \%$ \\
\hline \multicolumn{2}{|l|}{ Nature of internet users } \\
\hline Domestic & $80 \%$ \\
\hline Corporate & $20 \%$ \\
\hline Total & $100 \%$ \\
\hline
\end{tabular}


A total of 510 online questionnaires were administered in the study and 341 successfully completed questionnaires were obtained. This translates to a response rate of 77.5 percent. According to Saunders et al. (2012) a 35\% response rate is satisfactory for academic studies. 54\% of the respondents were males and $46 \%$ were females. This implies that most of the users of internet services are males. Furthermore, $80 \%$ of respondents were domestic users of internet services. On the other hand, $20 \%$ were corporate users of internet services.

15-25 years of age had a relatively low response proportion of participants (4\%). The age group 3545 years had the highest proportion of participants $(43 \%)$. The second highest proportion of participants included the age group 25-35 years (49\%). The age groups 55-65years and 65+ had the lowest proportion of participants $(3 \%)$ and $(1 \%)$ respectively. From the results, $3 \%$ of respondents had attained secondary education, $66 \%$ had a bachelor's degree, $31 \%$ had other qualifications. It is evident that the greatest percentage of respondents in the study were in possession of a bachelor's degree.

\section{Tests of Relationships}

The multiple regression analysis was performed in order to test the relationships between the independent variables (tangibility, reliability, responsiveness, assurance, empathy, price and location) and the dependent variable (customer satisfaction). The findings from the multiple regression analysis are presented below.

Table 2: Coefficients

Coefficients $^{s}$

\begin{tabular}{|c|c|c|c|c|c|c|c|c|}
\hline \multirow[b]{2}{*}{ Mads } & & \multicolumn{2}{|c|}{ Unstandardized Coefficients } & \multirow{2}{*}{$\begin{array}{c}\begin{array}{c}\text { Standardized } \\
\text { Coefficients }\end{array} \\
\text { Beta } \\
\end{array}$} & \multirow[b]{2}{*}{$t$} & \multirow[b]{2}{*}{ Siq. } & \multicolumn{2}{|c|}{ Collinearity Statistics } \\
\hline & & $\mathrm{B}$ & Std. Error & & & & Tolerance & $\mathrm{V} \mid \mathrm{F}$ \\
\hline \multirow[t]{7}{*}{1} & (Constant) & 4.376 & .441 & & 9.932 & .000 & & \\
\hline & Reliability & .460 & .124 & .230 & 3.721 & .000 & .476 & 2.103 \\
\hline & Empathy & -.270 & .138 & -.129 & -1.956 & .051 & .421 & 2.378 \\
\hline & Responsiveness & .421 & .095 & .249 & 4.447 & .000 & .578 & 1.729 \\
\hline & Tangibles & -.255 & .116 & -.126 & -2.199 & .029 & .551 & 1.813 \\
\hline & Location & -.118 & .106 & -.060 & -1.109 & .268 & .618 & 1.619 \\
\hline & Price & .653 & .067 & .480 & 9.738 & .000 & .747 & 1.338 \\
\hline
\end{tabular}

a. Dependent Variable: OverallSatisfaction

\section{Discussion and conclusion}

From the results, it can be noted that some of the independent variables displayed a statistically significant positive impact on customer satisfaction. In this vein, three of hypothesis were accepted, whereas three of the hypotheses were rejected. The first hypothesis (H1) of the study was accepted $(\beta=$ $0.230 ; \mathrm{p}=0.000)$. Thereby, implying that reliability has a statistically significant positive impact on customer satisfaction. This finding is in line with the findings by Samen et al. (2013) who found that reliability had a positive statistically significant impact on customer satisfaction within the Jordanian customers. On the other hand, the second hypothesis $(\mathrm{H} 2)$ in the study was accepted $(\beta=0.249 ; \mathrm{p}=$ 0.000 ). This finding implies that responsiveness has a statistically significant positive impact on customer satisfaction. This finding is in line with the assertions by Negi (2009) who purports that responsiveness is a key driver of customer satisfaction. The third hypothesis $(\mathrm{H} 3)$ in the study was not accepted $(\beta=-1.26$; $p$ $=0.029)$ which indicates that tangibles have no positive statistically significant impact on customer satisfaction. This finding is not in line with the findings of Wakefield and Blodgett (1994) who noted that tangibles positively influence customer satisfaction. Samen et al. (2013) argued that tangibles are an important service quality driver of customer satisfaction. The fourth hypothesis (H4) was not supported in the study $(\beta=-1.29 ; p=0.051)$. In this vein, it was noted that empathy was not a positive statistically significant predictor of customer satisfaction. This finding contrasts with the findings by Kumar, Tat Kee, and Taap Manshor (2009) who found that empathy had a positive impact on customer satisfaction. The fifth hypothesis (H5) in the study was not supported by the findings $(\beta=-0.60 ; p=0.268)$. This implies 
that location does not have a positive statistically significant impact on customer satisfaction. This finding is not in line with the findings by Nguyen (2014) who found that location had a statistically significant impact on customer satisfaction.

The sixth hypothesis (H6) in the study was supported by the findings. This implies that the price of the service charged to customers has a positive impact on their satisfaction with the service. This is in line with assertions by Chang, Chen and Hsu (2014) who argued that price as a service quality dimension has a positive impact on customer satisfaction. For contemporary organisations, service quality is a key driver in ensuring customer satisfaction. Organisations which can meet all the necessary service quality drivers in their services are able to satisfy the needs of their customers. In the internet service provision sector, several service quality dimensions have a positive impact on the satisfaction experienced by customers. The present study showed that the reliability of the internet service, responsiveness to customer needs and price of the internet service offered, had a positive impact on the satisfaction of the customers of the largest internet providing organisation in Zimbabwe. In this vein, the customers of internet services were noted to be sensitive to the reliability, responsiveness and price of the internet services provided. In order for internet providing organisations to survive and be profitable in Zimbabwe, it is imperative for them to ensure that they are reliable, responsive and price friendly to their customers.

\section{Implications of the findings}

The research analysis established that reliability and responsiveness were the most prominent service quality drivers of customer satisfaction in internet services provision. This therefore implies that internet services providers are encouraged to maintain high levels of engagement in reacting to customer requests and upholding the highest levels of trustworthiness in order to gain, retain and attract internet services customers.

\section{Limitations and directions for future research}

The present study adopted a cross-sectional quantitative design; hence, future studies can follow a longitudinal design. In this vein, the study of the impact of service quality on customer satisfaction can be investigated over an extended period of time. Furthermore, future research can employ a mixed method approach in which data collection will involve both survey questionnaires and in-depth interviews with respondents. As for theoretical contribution, further research could investigate the effect of price and reliability on customer satisfaction with location being the mediator. This would reveal how much of an important role that location could potentially play on customer satisfaction when price and reliability are involved. Lastly, future research can be in the form of a comparative study to ascertain the differences in the impact of service quality on customer satisfaction amongst customers who reside in different geographical provinces of Zimbabwe.

\section{References}

Agnihotri, R., Dingus, R., Hu, M. Y., \& Krush, M. T. (2016). Social media: Influencing customer satisfaction in B2B sales. Industrial Marketing Management, 53, 172-180.

Al-Wugayan, A., \& Pleshko, L.P. (2010). A Study of Satisfaction, Loyalty, and Market Share in Kuwait Banks. Academy for Studies in International Business, 10(1), 2-7.

Anselmsson, J. (2006). Sources of customer satisfaction with shopping malls: a comparative study of different customer segments. International Review of Retail, Distribution and Consumer Research, 16(1), 115-138.

Chang, K.C., Chen, M.C., \& Hsu, C.L. (2010). Applying loss aversion to assess the effect of customers' asymmetric responses to service quality on post-dining behavioural intentions: an empirical survey in the restaurant sector. International Journal Hospital Management, 29 (4), 620-631.

Chen, C. F., \& Chen, F. S. (2010). Experience quality, perceived value, satisfaction and behavioral intentions for heritage tourists. Tourism management, 31(1), 29-35.

Cheung, R., \& Vogel, D. (2013). Predicting user acceptance of collaborative technologies: An extension of the technology acceptance model for e-learning. Computers \& education, 63, 160-175.

Chidambaram, V. (2012). A review of customer satisfaction towards service quality of banking sector. Social and Management Sciences, 2, 71-79. 
Eshghi, A. (2008). Service quality and customer satisfaction. An empirical investigation in India mobile Telecommunications services. Marketing management journal, 18 (2), 119-144.

Fox, N., Hunn, A., \& Mathers, N. (2009). Sampling and Sample Size Calculation. The NIHR for the Research Design Service for the East Midlands. UK: Yorkshire and the Humber.

Gera, R. (2011). Modelling the service antecedents of favourable and unfavourable behaviour intentions in life insurance services in India: An SEM study. International Journal of Quality and Service Sciences, 3(2), $225-242$.

Ghylin, K.M., Green, B. D., Drury, C. G., Chen, J., Schultz, J.L., Uggirala, A., Abraham, J.K. \& Lawson, T.A. (2006). Clarifying the dimensions of four concepts of quality. Theoretical Issues in Ergonomics Science, 9(1), 73-94.

Giese, J. L., \& Cote, J. A. (2000). Defining consumer satisfaction. Academy of marketing science review, 1(1), 1-22.

Han, H., \& Ryu, K. (2009). The roles of the physical environment, price perception, and customer satisfaction in determining customer loyalty in the restaurant industry. Journal of hospitality $\mathcal{E}$ tourism research, 33(4), 487-510.

Johnson, M. D., \& Gustafsson, A. (2000). Improving customer satisfaction, loyalty and profit: an integrated measurement and management system. San Francisco, CA: Jossey-Bass.

Koenaite, M., Chuchu, T., \& Venter de Villiers, M. (2019). The impact of mobile banking on the adoption of banking products and services in South Africa, using the technology acceptance model. Journal of Business and Retail Management Research. 13(3), 93-103

Kotler, P. (2015). Marketing Management+ Mymarketinglab with Pearson Etext Access Card. Prentice Hall.

Kotler, P., Keller, K. (2009). Marketing management. New Jersey: Person education.

Kumar, M., Tat Kee, F., \& Taap Manshor, A. (2009). Determining the relative importance of critical factors in delivering service quality of banks: an application of dominance analysis in SERVQUAL model. Managing Service Quality: An International Journal, 19(2), 211-228.

Lin, H. F. (2007). The impact of website quality dimensions on customer satisfaction in the B2C e-commerce context. Total Quality Management and Business Excellence, 18(4), 363-378.

Masevo, B. (2015). Factors that influence innovation in the Paint manufacturing industry in Zimbabwe. A case of Solid Paints Company in Harare. Solusi University.

Mashwama, V.C., Chiliya, N., \& Chuchu T. (2019). Destination Image of Swaziland: Perceptions of Local and International Tourists. e-Review of Tourism Research 16(4), 271-293

Maziriri, E.T., \& Madinga, N.W. (2015). The Effect of buyer's remorse on consumer's repeat-purchase intention: Experiences of Generation Y apparel student consumers within the Vaal Triangle. International Journal of Research in Business Studies and Management, 2(5), 24-31.

Munusamy, J., Chelliah, S., \& Mun, H. W. (2010). Service quality delivery and its impact on customer satisfaction in the banking sector in Malaysia. International Journal of Innovation, Management and Technology, 1(4), 398-404

Negi, R. (2009). Determining customer satisfaction through perceived service quality. International journal of mobile marketing, 4, (1), 31-38.

Nguyen, M. T. (2014). Effects of Service Quality and Price Fairness on Student Satisfaction. International Journal of Business and Social Science, 3(19), 132-150

Parasuraman, A. Z. (1988). SERVQUAL: A multi-item scale for measuring consumer perceptions of service quality. Journal of Retailing, 64, 12-40.

Samen, A., Akroush, M., \& Abu-Lail, B. (2013). Mobile SERVQUAL: A comparative analysis of customers' and managers' perceptions. International Journal of Quality \& Reliability Management, 30(4), 403-425.

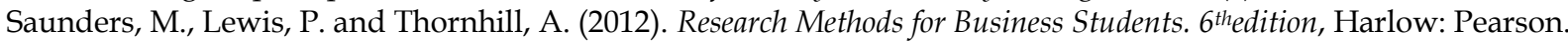

Sullivan, M. J., Suddeth, B. N., Vardell, T., \& Vojdani, A. (1996). Interruption costs, customer satisfaction and expectations for service reliability. IEEE Transactions on Power Systems, 11(2), 989-995.

Tahir, H., Waggett, C., \& Hoffman, A. (2013). Antecedents of customer satisfaction: An E-CRM framework. Journal of Business and Behavioral Sciences, 25 (2), 112-120.

Wakefield, K., \& Blodgett, J. (1994). The Importance of Servicescapes in Leisure Service Settings. Journal of Services Marketing, 8(3), 66-76.

Wilson A., Zeithaml V.A., Bitner M.J., \& Gremler D.D. (2008) Services Marketing. McGraw-Hill Education 